Семененко Л. М.

кандидат філологічних наук, дочент Криворізький педагогічний інститут ДВНЗ «Криворізький наиіональний університет»

\title{
ДИСКУРС РОДИННОГО БУТТЯ У ТВОРІ ОЛЬГИ КОБИЛЯНСЬКОЇ «ЗЕМЛЯ»
}

У статті розглядаються особливості художньої реалізаиії дискурсу родинного буття у творі Ольги Кобилянської «Земля». Розкрито специфіку психологічного малюнка родинних стосунків у творі, визначено та проаналізовано різні моделі шлюбного життя, окреслені письменницею в аналізованому тексті.

Ключові слова: дискурс, родинне буття, художня модель.

В статье рассматриваются особенности художественной реализации дискурса семейного бытия в произведении Ольги Кобилянской «Земля». Раскрыта специфика психологического рисунка семейных отночений в произведении, определены и проанализированы разные модели брачной жизни, очерченные писательницей в анализируемом тексте.

Ключевые слова: дискурс, семейное бытие, художественная модель.

In the article the features of artistic realization of diskurs of domestic life are examined in work of Olga Kobilyanskoy «Earth». The specific of psychological picture 
of domestic relations is exposed in work, the features of characters are given, what represented in domestic life. The different models of marriage life, outlined an authoress in text of work, are selected an author and analysed. Basic attention is spared the change of basic domestic values which were actual for different characters of work and activity of characters in their achievement.

Key words: diskurs, domestic life, artistic model.

Творчість однієї з кращих представниць української літератури періоду зламу XIX i XX століть Ольги Кобилянської припадає на той час, коли література переживала період оновлення, коли актуалізувалися нові творчі шукання, марковані поняттям модернізм. Модерний (новаторський) підхід до літератури передбачав звернення авторів до нового художнього осмислення світу та місця в ньому особистості, що втілювалося насамперед у зміні стильових орієнтирів, заглибленні в психологію окремої особистості.

Ольга Кобилянська була активною учасницею літературномистецького буття своєї доби, вона творила в руслі модерністських, переважно неоромантичних тенденцій. Неоромантичний підхід передбачав, насамперед, абсолютизацію почуттів сильної особистості; важливою бачилася спроба зображення проблематики, пов'язаної з актуалізацією напруженого внутрішнього буття людини, розкриттям конфліктних опозицій між ідеалом і дійсністю. Такий підхід дозволив створити своєрідну галерею ідейно та художньо значущих постатей, здатних зробити сподіване дійсним, кардинально змінити життя завдяки потужній силі волі, наполегливості, стійкості. Сутністю художнього зображення у прозі авторки став своєрідний перехід від традиційних моделей та дискурсів, пов'язаних 3 «жіночою» проблематикою, до цілком нових образів, тем, проблем, маргінальних для існуючої літературно-культурної традиції.

У літературі кінця XIX - початку XX століття набрав гостроти головний конфлікт між народництвом, $з$ його орієнтацією на збереження культурно-національної ідентичності, і модернізмом новим естетичним і політичним принципом XX століття, що оріє- 
нтувався на загальноєвропейський процес та його універсалізм. Проте, як писала С. Павличко, «між двома парадигмами, існувала ще одна ключова опозиція - жіночого і чоловічого, або феміністичного і патріархального, яку иілком ясно усвідомлювали всі учасники изього літературного дискурсу» [Павличко 1999: 21]. На слушну думку дослідниці, Ольга Кобилянська кинула виклик домінуючій чоловічій традиції, бо відчувала себе спадкоємницею зрілої традиції «жіночої літератури», маючи своїми попередницями Марка Вовчка і Ганну Барвінок, Олену Пчілку та Наталю Кобринську. Різні варіанти підходу до проблем родинного життя представлені письменницею у багатоплановому творі «Земля». Авторка розглядає подружнє життя на прикладі кількох пар протягом життя двох поколінь, моделюючи різні аспекти сімейних стосунків.

Отже, мета статті полягає у висвітленні дискурсу родинного буття у творі Ольги Кобилянської «Земля».

Як слушно вказувала С. Павличко, в романі «демістикувалися й деміфологізувалися ключові поняття, святі для народницького світогляду: ідеальність громади, ідеальність природної людини, украӥния-селянина, ідеальність селянської сім'ї, ідеальність жінки. О. Кобилянська вважала, щзо романтична чистота стосунків між людьми й сімейна гармонія - міф. У селі, на землі панує насильство, інстинкти, сексуальні пристрасті, злоба сусідів, взаємна заздpicmь» [Павличко 1999: 63]. Дослідниця підкреслює, що «шлюби 3 розрахунку сполучені із взаємною ненавистю. Тиранія батьків доходить до звірства. Людська природа, не обмежена й не відшліфована культурою, виявляється огидною, а людські стосунки деформованими патріархальними нормами» [Павличко 1999: 63].

Роман починається з експозиції, де подається сцена весілля персонажів, які потім не будуть брати прямої участі в дії. Ініціатором одруження стає мати нареченої Докія, а причиною - прагнення матері забезпечити доньці безбідне, а, отже, пристойне життя. Чоловік Докії - пияк, тому мати боїться, що він проп’є землю, призначену для дочки («Коли б Парасинка мала раз чоловіка, все 
пішло б іншою ходою: особливо ж, коли б ї̈ вже не стало. Вона лиш того боялася. Він не допустив би, щуоб старий винаймив поле жидові, - се було би першою роботою його по ї смерті, - або щзоб його задовжував. Він узяв би газдівство в свої руки і примусив би пияка сидіти тихо на печі» [Кобилянська 1954: 11]. Через те Докія поспішає видати дівчину заміж, хоча Парасинка має всього шістнадцять років, а наречений Тодорика - далеко не красень. Вибір нареченого зумовлюється у творі двома чинниками: в нього порядні батьки і земля Тодорики знаходиться поруч із землею Парасинки. Така інтерпретація причин одруження є цілком традиційною для української літератури (можна пригадати хоча б «Наталку Полтавку» Івана Котляревського). Мрії Докії про подружнє життя доньки обертаються переважно навколо землі й не виходять за межі традиційних уявлень про родинне життя: «Парасинка буде з ним щаслива. Зразу буде мешкати з його старими, аби навчитися їх ладу, навчитися їх слухати і придивитися старій матері, як вона сина доглядає, а потім заживе з чоловіком сама окремо... Вона хоче лище добра для доньки $і$ щастя, хоче бачити ї̈ своєю газдинею $i$ за чоловіком, як ї̈ дні вийдуть і смерть заморозить ї̈ тіло» [Кобилянська 1954: 13]. Частиною світогляду матері є переконання, що «жінка призначена чоловікові, як смерть від бога» [Кобилянська 1954: 16].

Отже, важливим для осягнення змісту роману стає те, що, як указує В. Агеєва, «мати із найкращчх спонук, влаштовує невдале й нещасливе подружжя неповнолітньої доньки» [Агеєва 2003 : 52].

У традиційному руслі представлене життя сім’ї Федорчуків, батьків Михайла та Сави, по-іншому розставлено лише акценти. Розгортаючи картини родинного буття Івоніки та Марійки Федорчуків, письменниця підкреслює, що основним підгрунтям міцного шлюбу є спільна мета: Івоніка й Марійка все життя працюють, щоб накопичити землю, стати «красними газдами»: «Пощо чоловік живе? Не на те, аби робив? Як колись замкну очі, то хочу, аби моя земля перейшла в робучі руки. Я й моя Марійка - ми обоє до- 
робилися ï̈, отсими нашими руками дороблялися ї̈. Вона підпливала нашою кров'ю $і$ нашим потом. Кожна грудка може посвідчити, як часто голодом і холодом ми годувалися, аби зароблене не йшло на кусник хліба, але на неї》 [Кобилянська 1954: 24]. Такий спосіб життя оцінюється персонажами як цілком природний і єдино можливий, що теж відповідає літературній традиції. Батько мріє і про гучне весілля для свого старшого сина: «Відтак справлю Михайлові таке весілля, якого ще наше село не виділо. Хліба та булок куплю в Чернівиях. Увесь мій мед піде в горівку. Заріжу корову, циган візьму з Глиниці. Гратимуть у мене иілий тиждень. Десять років будуть люди згадувати, яке весілля справив Івоніка своєму Михайлові〉 [Кобилянська 1954: 28]. Однак традиційних цінностей виявляється замало для виховання синів. Михайло й Сава дуже різні за характерами й поглядами на світ. Спільним між ними, поряд із іншими чинниками, $є$ те, що обидва обирають тих дівчат, які не будуть бажаними невістками для батьків. При цьому обрані братами дівчата теж дуже різні. Обраницею Михайла є Анна, характер якої має у тексті твору явно позитивне забарвлення: вродлива, працьовита, привітна, щира, сильна духом, - далеко не повний перелік рис дівчини. Стосунки Михайла й Анни зображує письменниця підкреслено людяними. У проникливій сцені признання в коханні Анна, яка звикла до зневаги, тому що не має землі, на цьому ж і наголошує, не вірячи спочатку в своє щастя. Для закоханого хлопця наявність / відсутність землі та статків не має значення («Я не питаю за поле, зозулько!»): «Я тебе люблю, Анно, вже віддавна! Ти така гарна й добра! Хочу тебе взяти за жінку, тебе одну, одніську! Ти мусиш мені сказати, чи ти хочеш $і$ чи ти любиш мене?» [Кобилянська 1954: 75]. Однак романтична окресленість стосунків цих персонажів у своєрідний спосіб «урівноважується» у творі цілим рядом символічних знаків долі, які час від часу з'являються в тексті. Зокрема, на весіллі Парасинки, представленому в експозиції твору, Анна спостерігає за Михайлом і дивується, чому Парасинка «замикає» очі, коли танцює з Михайлом. 
Зрештою, коли Михайло запрошує до танцю Анну, обривається струна, музика замовкає і «не зіткнувшись, розлучилися дві руки». Пізніше щасливій Анні дається видіння - «закривавлені вогняні имати з двома розжареними несамовитими очима» [Кобилянська 1954: 82], які летять з боку темного «сусіднього» лісу. Усі передчуття здійснюються, всі видіння справджуються, - закохані не будуть разом. Таким же містичним елементом виступає промовиста художня деталь: коли на похороні Михайла мати пробує вигнати Анну, в Михайла починає йти кров. Цей факт коментується людьми як визнання правди Анни, оскільки «кров Михайла їі захищає».

Натомість Рахіра, обраниця Сави, негарна, ледача, брутальна, злодійкувата, нахабна, що впадає в очі батькам: «Сором нам робиш, Саво! Ти любиш дівчину пусту, щуо на неї ні один порядний хлопещь у селі не глядить, що ї̈ ніхто порядний за жінку не візьме...» [Кобилянська 1954: 33]. Саме така дівчина викликає в Сави сильні почуття, здатна утримати його біля себе: «B ї̈ обіймах він неначе мінився. Своӥми великими червоними устами пила з нього всю енергію і силу; пила його, коли лиш гляділа на нього своїми очима. I під тими поглядами, що або сміялися, або іскрами обсипували його, -м'як, ослабав і тратив усяку волю. Ї̈ сміх, голосний, короткий, уриваний сміх, виривав його з усякого надумування й поривав із собою, а слова ї̈ все підходили йому під його душевний лад» [Кобилянська 1954: 33]. Рахіра сама упадає коло Сави, намовляе його вбити Михайла, аби скористатися спадком. У Саві Рахіра бачить не лише свого коханця та близьку людину, але й засіб реабілітувати себе в очах односельців, які знають їі як злодійкувату, нахабну особу. Додатковим чинником прив'язаності Сави є й те, що в сім'ї коханої немає таких стійких морально-етичних обмежень, які хлопець мав у своїй родині, отже, значущим є відчуття більшої свободи. Ситуація неприйняття Рахіри батьками Сави ускладнюється тим, що дівчина доводиться Саві двоюрідною сестрою. Зрештою, саме гріхом кровозмішення пояснює трагедію братовбивства Івоніка, сприймаючи страшну подію як покарання за 
гріх крові. Письменниця підкреслює, що навіть одружившися 3 Рахірою, Сава не знаходить душевного спокою, його внутрішнє життя цілком занепадає: «Кажуть: він усе був такий непостійний, але щзо не мав ї̈, то ходив до неї, а тепер як ї̈ має, шукає чогось іншого... Це ж було щуось заборонене, щзось темне, чого він не любив. Воно втиснулося насилу в його молоду душу, в його убоге душевне життя, $і$ як займило ї̈ иілковито для себе - втратив те душевне життя. Вона випила з нього душевну благородність до останньої краплі, а стративщи се - стратив $i$ себе самого» [Кобилянська 1954: 317].

Якщо Сава хоче мати й землю, і Рахіру, то Михайло осмислює ситуацію інакше. Письменниця наголошує, що Михайло не хоче втратити добрі стосунки з батьками, тому жде дня свого святого покровителя Михайла, щоб повідомити батьків про вибір майбутньої дружини. Сімейні стосунки й думка батьків дуже багато важать для хлопця. Водночас заради Анни Михайло готовий відступитися від найбільш культивованої цінності - землі, якщо несприятливо складуться обставини й батьки не погодяться на шлюб сина: «Тоді скажу: або мати мене з Анною тут при собі, або мати мене з Анною в місті. Тоді вже вони зм'якнуть, не бійся. Ти ж не Рахіра. Ти не моя перва сестра і цее не гріх, щуо ми любимося. Наша милість не потягне за собою гріхів і біди. Іншої причини не мають вони, щоби нас розлучити... Я лишу вам усе поле, скажу я їм, тіштеся ним, а я беру собі Панну й верну назад до міста. Там я вже знайду собі роботу й не згину. Тепер я вже інакше думаю, як раніше, я вже обглянувся трохи на світі $і$ знаю, щзо чоловік, який має добру волю до праці $і$ здорові руки, не згине з голоду. В місті живуть люди й без землі» [Кобилянська 1954: 212213]. Цілком у руслі модерністських тенденцій, які передбачають, зокрема, культ почуття, письменниця підкреслює значущість кохання в житті людини: «Як чоловікові жінка мила, то так, якби вона його очима була» [Кобилянська 1954: 213]. Особливе місце посідає кохання взаємне, саме воно дає силу Михайлові пережити знущання 
у війську, а Анні - чекати Михайла, терпіти зневагу з боку односельців та рідних, до останнього тримати в таємниці їх стосунки.

Виховуючись в одній родині, Михайло і Сава стали цілком різними людьми. Письменниця підкреслює спадковий чинник (Михайло вдався у батька, а Сава в матір, якій так і не вдається піднятися над рівнем простих життєвих реакцій. Тому ії фанатична любов до Сави трансформувалась у таку ж фанатичну ненависть). Тісний психічний зв’язок між матір'ю й сином відчуває Анна. Одначе материна емоційність не визначила цілком характер Сави, а була лише його зародком. Корені ж Савиної душі, причини його агресивної життєвої позиції перебувають у сфері підсвідомого, про що свідчать його очі - не схожі ні на батькові, ні на материні. О. Кобилянська лише констатує факт. Зіставлення контрастних портретних деталей (краса обличчя й холодність очей) підкреслює подвійність Савиної натури, а також те, як на ньому позначається батькова й материна спадковість.

Після смерті Михайла родинне життя Федорчуків набуває цілком інших реалій. Вони відмовляються від Сави, хоч і не доносять слідству, що вбивця саме він. Марійка «стала уникати людей, відпихати ворожо від себе всіх, щз зближалися приязно до неї, $i$ понурилася иілковито у свій жаль, з якого не було виходу. Часом пригадувала йому в своїи ненависті чим-небудь Саву, але він не застановлявся ніколи над тим. Бачив лише одно з великим смутком, як із ї̈ колись такої теплої й щирої душі виростала чимраз страшніша ненависть до дитини, і як в їі душі зайшло сонце навіки» [Кобилянська 1954: 288]. Затятість Марійки (вона відмовилася взяти до себе дитину Михайла й Анни) призводить ще до однієї трагедії: близнюки померли й батьки залишилися самотніми. Будучи порядною жінкою, Марійка надалі гірко жалкує про вчинений гріх, який і iї саму позбавив радості, яку вона могла мати 3 онуками. Надалі відбувається своєрідна зміна гендерних ролей: Марійка не може подолати себе, тому залишається осторонь, замикається в собі, натомість Івоніка вдається до більш активних 
дій. «Невісткою своєю називає їі, і гірко - болісно всміхається при тім, сам із себе. Хлопчину ї̈ медом угощає $i$, як внука, голубить. Се одинокий золотий промінчик на тихих полях, що викликує від часу до часу усміх на його устах $і$ щсо ним він справді радується» [Кобилянська 1954: 292]. Він переписує найкращий шматок землі, який призначався Михайлові, на сина Анни й Петра, поводиться 3 хлопчиком, як із своїм онуком. У такий спосіб до дискурсу родинного буття, представленого у творі, додаються міфологеми злочину й кари, прощення та спокути.

Актуальним у контексті дискурсу сімейного буття, представленого у творі «Земля», є те, що значущою ознакою руйнування старого патріархального сімейного укладу стає десакралізація образу матері, послідовно представлена в різних буттєвих ситуаціях. Докія віддає доньку заміж за нелюба лише тому, що земля Тодорики знаходиться поруч із землею Парасинки, й тому, що батько надалі може пропити або закласти цю землю. Марійка, як уже зазначалося, відштовхує обраницю свого сина Анну та його дітей, через що страждає сама. Мати Анни зневажає дочку, що не заважає їй відбирати в дівчини все зароблене. Зрештою, в сім'ї Рахіри слово матері не має ніякого значення. Така деструкція сакрального для української культури образу стала показовою і в символічному сенсі, оскільки вивила тенденцію руйнування традиційного поняття українства та необхідність його модернізації.

Важливий аспект дискурсу родинного буття художньо реалізовано в зображенні шлюбного життя Анни й Петра. Їх родинне буття грунтується на взаємоповазі, визнанні кращих рис кожного: «Що чоловік без жіночих рук? Глина. А ще на старість... А Аннащзо вже було з нею, то було, - а вона все-таки не з тих, аби ій не варто честі віддати» [Кобилянська 1954: 318]. Подружжя наполегливо працює, «складає статки», але живе не для накопичення багатства, а для сина: «П'ятий рік живуть уже разом. В них коло хати рівновага й лад. Той лад, щчо його витворює невтомима праџя і ясний твердий розум. Петро відмолоднів і мов удвоє подужав. 
Працює, товчеться, вештається $i$ - як говорять люди, жартуючи на старість маєтки збиває. Добре живуть. Вона дуже добре дбає про нього. Совісна й уважна, мов коло скла, коло нього ходить» [Кобилянська 1954: 319]. Письменниця об'єднує персонажів спільністю поглядів на майбутнє дитини («3 нього будуть люди, як покине землю! Якісь інші люди, як вона, як всі ті, щуо окружають іï... Не розуміє ясно, чому, по якій причині, але відчуває се й щиро переконана. А Петро піддержує ї̈ в тім» [Кобилянська 1954: 319]).

Увага привертається до своєрідного містицизму, наперед зумовленої долі основних персонажів. Такий підхід підтверджується епіграфом із твору норвезького автора Юнаса Лі: «Кругом нас знаходиться якась безодня, щзо ї̈ вирила доля, але тут, у наших сериях, вона найглибша» [Кобилянська 1954: 19].

Отже, в романі «Земля» Ольга Кобилянська подає цілком різні вияви родинного буття, розгортаючи їх на основі почуттів персонажів, підкреслює варіативність причин заміжжя / одруження, актуалізує ряд моделей подружнього життя. Важливим є те, що гармонізації набувають такі стосунки персонажів, які грунтуються на щирих почуттях, взаємодовірі та взаємоповазі.

\section{БІБЛІОГРАФІЯ}

Агеєва 2003 - Агеєва В. П. Жіночий простір: Феміністичний дискурс українського модернізму : [монографія]. - К. : Факт, 2003. - 320 с.

Кобилянська 1954 - Кобилянська О. Ю. Земля. - К. : Державне видавництво художньої літератури, 1954. - 340 с.

Нікітчина Г. Д. Почуттєве задзеркалля Ольги Кобилянської (психоаналітичне тлумачення автобіографічних текстів письменниці) Вісник Львівського університету. Серія філологічна. - Випуск 33: Теорія літератури та порівняльне літературознавство. - Львів, 2004. - С. 229-38. - Режим доступу:

http://www.anthropos.org.ua/dspace/handle/123456789/247

Павличко 1999 - Павличко С. Д. Дискурс модернізму в українській літературі [монографія]. - К. : Либідь, 1999. - 447 с.

Пахаренко 1999 - Пахаренко В. Погляд у безодню // Українська мова і література в школі. - 1999. - № 1. - С. 3-4.

Шостак 2004 - Шостак А. Архетип матері у повісті Ольги Кобилянської «Земля» // Літературознавчі студії. - К. : Видав. центр «Київський університет», 2004. C. 218-222.

Стаття надійшла 15 січня 2014 р. 